\title{
Product Development from Jackfruit (Artocarpus heterophyllus) and Analysis of Nutritional Quality of the Processed Products
}

\author{
C. Mondal ${ }^{1}$, R. N. Remme ${ }^{1 *}$, A.A. Mamun ${ }^{2}$, S. Sultana ${ }^{2}$, M. H. Ali ${ }^{3}$, \\ M.A. Mannan ${ }^{4}$ \\ 1,3 (Student, Agrotechnology Discipline, Khulna University) \\ ${ }^{1 *}$ (Lecturer, Agrotechnology Discipline, Khulna University) \\ ${ }^{2}$ (Asst. Professor, Agrotechnology Discipline, Khulna University) \\ ${ }^{4}$ (Professor, Agrotechnology Discipline, Khulna University)
}

\begin{abstract}
The present experiment was conducted at the Molecular Horticulture Lab. of Agrotechnology Discipline, Khulna University to develop products by processing different parts of jackfruits and to evaluate the nutritional quality of the processed products. The highest total soluble solids were observed from jelly (65.00 $\%)$. The highest $\mathrm{pH}$ was also found in jelly (5.047). Green pickle contains highest amount of vitamin-C (3.4433 $\mathrm{mg} / 100 \mathrm{~g})$ and carotinoids $(22.78 \mathrm{mg} / 100 \mathrm{~g}$ ). Sweet pickle contains the highest amount of moisture $(50.95 \%)$. After six months of storage, quality of the processed products regarding color, taste, flavour and texture were similar to that of freshly processed products. But after 8-9 months of storage the quality of jam, jelly and squash started to deteriorate and the quality of pickles (i.e., green pickle and sweet-pickle) remain unchanged even after 12 months of storage.
\end{abstract}

Key words: Jam, Jelly, Pickle, squash, Jackfruit

\section{Introduction}

Jackfruit is a dicotyledonous compound fruit of the jack tree (Artocarpus heterophyllus L.) which belongs to the family Moraceae grow in many of the tropical countries of Southeast Asia but is particularly abundant in India and Bangladesh. Jackfruit is recognized as the National Fruit of Bangladesh. Jackfruit is grown in all districts. The highest volume of production takes place in Dhaka, Gazipur, Tangail, Khagrachari, Rangamati, Mymensingh, Moulvibazar, Narsingdi, Dinajpur and Rangpur. Presently, Bangladesh cultivates jackfruits in 79 thousands hectares of land producing about 1,352,000 tons fruits in a year. Yield per hectare is 17 metric ton. A small quantity of about 60 metric ton fresh jackfruit and some seeds are exported to UK (Action plan, 2013) ${ }^{[1]}$. People consumed it mostly as a fruit when ripe but also as vegetable in the unripe stage. The jackfruit significantly contributes to the nutrition of the people of this country as a source of vitamins, minerals and calories. Both tender and ripe fruits as well as the seeds are rich in minerals and vitamins. It is grown and sold in the market almost everywhere in the country. The primary economic product of jackfruit is the fruit, used both when immature and when mature. The fruit pulp is sweet and tasty and used as dessert or preserved in syrup. The seeds contained in the ripe fruits are also cooked. The fruits and seeds are also processed in a variety of ways for food and other products.

Jackfruit have more protein, calcium, thiamine, riboflavin and carotene than banana but less nutritious than mango (Hossain et al., 1979) ${ }^{[2]}$. The yield of jackfruit is $10.5 \mathrm{t} / \mathrm{ha}$ which is manifold higher than mango, 4.76 t/ha $(\mathrm{BBS}, 2007){ }^{[3]}$. Therefore, vitamin and mineral production per unit area are higher in jackfruit than Mango. Edible bulbs of ripe jackfruit (Artocarpus heterophyllus L.) are consumed for their fine taste and pleasant aroma.

Jackfruit is rich in dietary fiber, which makes it a good bulk laxative. The fiber content helps to protect the colon mucous membrane by decreasing exposure time and as well as binding to cancer-causing chemicals in the colon. Fresh fruit has small amounts of vitamin-A, and flavonoid pigments such as carotene- $\beta$, xanthin, lutein and cryptoxanthin- $\beta$. Together, these compounds play vital roles in antioxidant and vision functions.

Vitamin A is also required for maintaining integrity of mucus membranes and skin. Consumption of natural fruits rich in vitamin-A, and carotenes has been found to protect from lung and oral cavity cancers. addition, jackfruit is a good source of antioxidant vitamin-C, provides about $13.7 \mathrm{mg}$ or $23 \%$ of RDA. Consumption of foods rich in vitamin $\mathrm{C}$ helps the body develop resistance against infectious agents and scavenge harmful free radicals. It is one of the rare fruits that is rich in B-complex group of vitamins. It contains very good amounts of vitamin B-6 (pyridoxine), niacin, riboflavin, and folic acid. Fresh fruit is a good source of potassium, magnesium, manganese, and iron. Potassium is an important component of cell and body fluids that helps controlling heart rate and blood pressure (SCUC, 2006) ${ }^{[4]}$. 
However, the fruit is perishable and cannot be stored for long time because of its inherent compositional and textural characteristics. In every year, a considerable amount of jackfruit, specially obtained in the glut season (June-July) in every year goes waste due to lack of proper postharvest knowledge during harvesting, transporting and storing both in quality and quantity. Proper postharvest technology for prolonging shelf life is, therefore, necessary. Besides, alternate ways of using jackfruits in on-season plays significant roles in reducing postharvest losses. Among them, processing is important one. It adds diversified and attractive food items in dietary menu as well as contributes to generation of income and employment.

A number of products have been developed from raw, tender and ripe fruits and seeds. The ripe fruit bulbs (excluding seed) and the rind of the ripe fruit (including perianth and unfertilised flowers) have been used for processing in a number of products. Ripe jackfruit bulbs are canned in syrup, made into jams either pure or mixed with dehydrated bulbs, chutney, preserves, candy, and concentrate and powder. Rinds of ripe fruit are made into jelly. Preservation of fruits by processing has been the research pursuits of many developed and developing countries and has yielded quite a number of technologies. Home and cottage level processing of some fruits, specially 'Berry, Tamarind, Indian olive,' etc. exists in Bangladesh. However, processing techniques of jackfruit is very scanty in Bangladesh. There has been a little research work mentioning to find possibility of processing of jackfruit into durable and nutritious food products. So, it is now a burning issue to reduce the losses by developing the processing technique of jackfruit. Cottage industries and small scale industries establishment can be encouraged in our country, efforts of which are as yet quite inadequate. It can be hoped that a continuous increase of the agro based industries, unemployed people can be provided with work through auxiliary and useful services which would lead the rural life more prosperous in near future. In consideration of the above circumstances, the present study was under taken to develop products by processing different parts of jackfruits and to know the nutritional quality of the processed products.

\subsection{Experimental design and method of analysis}

\section{Materials and Methods}

To develop product from the jack fruits, the experiments were laid out considering three replications with 3 to 5 formulations. The formulations of the experiments have been shown in the Table 1, 2, 3, 4, 5 and 6 . Completely Randomized Design (CRD) was applied for the analysis of experimental data. Sensory evaluation of jackfruit products were done following the technique adopted by Hossain and Siddique (1982) ${ }^{[5]}$. Least Significant Difference (LSD) was applied to assess the significance of nutrient elements of process products.

\subsection{Green jackfruit pickle}

Green, well-developed, tender seeded fresh jackfruits were selected. The fruits were collected carefully to avoid the latex-touch to the rind.

Table 1. Formulations for green jackfruit pickle

Formulations of the recipes were shown in the Table 1.

\begin{tabular}{|c|l|c|c|c|c|c|}
\hline Sl. & Ingredients & $\mathrm{T}_{1}$ & $\mathrm{~T}_{2}$ & $\mathrm{~T}_{3}$ & $\mathrm{~T}_{4}$ & $\mathrm{~T}_{5}$ \\
\hline 01 & Jackfruit (g) & 500 & 500 & 500 & 500 & 500 \\
\hline 02 & Mustard oil (ml) & 125 & 125 & 125 & 125 & 125 \\
\hline 03 & Sugar (g) & 27.5 & 30 & 37 & 40 & 42.5 \\
\hline 04 & Zinger (g) & 12.5 & 12.5 & 10 & 10 & 10 \\
\hline 05 & Mustard powder (g) & 7.5 & 3.75 & 5.6 & 5.6 & 5.6 \\
\hline 06 & Pepper (g) & 7.5 & 3.75 & 3.6 & 3.6 & 3.6 \\
\hline 07 & Dried peeper (piece) & - & - & 3 & 3 & 3 \\
\hline 08 & Turmeric (g) & 2.5 & 1.5 & 2.5 & 2.5 & 2.5 \\
\hline 09 & Cumin (g) & 2 & 1 & 1.5 & 1.5 & 1.5 \\
\hline 10 & Aniseed (g) & 2.5 & 1.25 & 1.5 & 1.5 & 1.5 \\
\hline 11 & Fenugreek (g) & 2 & 1 & 2 & 2 & 2 \\
\hline 12 & Black cumin (g) & 1 & 1 & 1 & 1 & 1 \\
\hline 13 & Cinnamon (g) & 2.5 & 1.25 & 1.5 & 1.5 & 1.5 \\
\hline 14 & Cardamom (piece) & 1 & 1 & 1 & 1 & 1 \\
\hline 15 & Salt (g) & 50 & 50 & 50 & 50 & 50 \\
\hline 16 & Vinegar (ml) & 125 & 125 & 100 & 100 & 100 \\
\hline 17 & Bay leaf(piece) & - & - & 2 & 2 & 2 \\
\hline 18 & Clove (piece) & - & - & 4 & 4 & 4 \\
\hline
\end{tabular}

A modified flow chart of green jackfruit pickle (Tilak, 1995) ${ }^{[6]}$ preparation is given in the Diagram 1.

Collection of green jackfruit

Wathing 3-5 times

Peeling and slicing

Dipping in brine solution

Removing frombrine solution and weighing 


\author{
Blanthing \\ Adding in fried spices mixed oil \\ Sauteing and adding rest spices and vinegar \\ Continued sa téing up to final cooking \\ Bottling and capping \\ Pastelizization at $85^{\circ} \mathrm{C}$ \\ Cleaning and labeling \\ Storing in a cool and dry place
}

Diagram 1: Flow diagram for preparation of green jackfruit pickle.

\title{
2.3 Jackfruit rind jelly
}

Formulations of the recipes were shown in the Table 2

Table 2. Formulations for jackfruit rind jelly

\begin{tabular}{|c|l|c|c|c|c|}
\hline Sl. & Ingredients & $\mathrm{T}_{1}$ & $\mathrm{~T}_{2}$ & $\mathrm{~T}_{3}$ & $\mathrm{~T}_{4}$ \\
\hline 01 & Jackfruit juice $(\mathrm{ml})$ & 500 & 500 & 500 & 500 \\
\hline 02 & Sugar $(\mathrm{g})$ & 300 & 350 & 200 & 250 \\
\hline 03 & Citric acid $(\mathrm{g})$ & 10 & 3 & - & - \\
\hline 04 & Pectin $(\mathrm{g})$ & 15 & 5 & 5 & 10 \\
\hline 05 & Agar $(\mathrm{g})$ & 10 & - & - & 2 \\
\hline 06 & KMS (g) & - & - & - & 0.7 \\
\hline 07 & Lemon (piece) & - & 1 & 1 & - \\
\hline
\end{tabular}

A modified flow diagram of jackfruit rind jelly preparation (Tilak, 1995) ${ }^{[6]}$ is given in the Diagram 2.

Selection fully matured, fresh ripen jackfruit

Wakhing 3-5 times

Rind separation and cutting in to small pieces

Adding vater and citric acid

Boiling 35 mihutes and extracting juice

Adding sugar and citrinc acid with juice and start cooking

Cooking continued to $\int \mathrm{TSS} 65^{\circ}$ and added rest citric acid

Determining the end point of cooking

Bottling and waxing

Labeling and storing in cool and dry places

Diagram 2: Flow diagram for preparation of jackfruit rind jelly.

\subsection{Jackfruit bulb jelly and jam}

Well-matured jackfruits were collected and it was washed reasonably with fresh water and bulbs were separated carefully. Then it was cut into small pieces and blended it in the blender and filtrated through the filter paper. The filtrate containing juice was taken for preparing jelly. Pectin was mixed well with sugar. The saucepan was placed on a burner for cooking. Then pectin and sugar mixture added into it and stirred. When TSS reached 66 to $67 \%$ the mixture was removed from the burner which indicates the end point of jelly preparation. KMS was dissolved in $10 \mathrm{ml}$ warm water and it was added to the mixture. Jackfruit juice and agar was also mixed in to the solution as described in the Table 3 in case of jam preparation Sodium benzoate was dissolved in $10 \mathrm{ml}$ warm water and it was added to the mixture. Lemon juice and citric acid were also mixed in to the solution as described in the Table 4.

Table 3. Formulations for jackfruit bulb jelly

\begin{tabular}{|l|l|c|c|c|c|}
\hline Sl. & Ingredients & $\mathrm{T}_{1}$ & $\mathrm{~T}_{2}$ & $\mathrm{~T}_{3}$ & $\mathrm{~T}_{4}$ \\
\hline 01 & Jackfruit juice $(\mathrm{ml})$ & 450 & 450 & 450 & 450 \\
\hline 02 & Sugar $(\mathrm{g})$ & 150 & 120 & 50 & 45 \\
\hline 03 & Citric acid (g) & 2 & 1.5 & 1.5 & 2 \\
\hline 04 & Pectin (g) & 5 & 5 & 5 & 5 \\
\hline 05 & Agar (g) & 1 & 1 & 1 & 1 \\
\hline 06 & KMS (g) & 0.30 & 0.30 & 0.30 & 0.30 \\
\hline 07 & Lemon (piece) & Half & Half & Half & Half \\
\hline 08 & Water (ml) & 450 & 450 & 450 & 450 \\
\hline
\end{tabular}

Table 4. Formulations for jackfruit jam

\begin{tabular}{|l|l|c|c|c|}
\hline Sl. & Ingredients & $\mathrm{T}_{1}$ & $\mathrm{~T}_{2}$ & $\mathrm{~T}_{3}$ \\
\hline 01 & Jackfruit pulp $(\mathrm{ml})$ & 450 & 450 & 450 \\
\hline 02 & Sugar $(\mathrm{g})$ & 225 & 200 & 150 \\
\hline 03 & Citric acid $(\mathrm{g})$ & 2.5 & 2.5 & 2.5 \\
\hline
\end{tabular}




\begin{tabular}{|l|l|c|c|c|}
\hline 04 & Pectin $(\mathrm{g})$ & 5 & 5 & 5 \\
\hline 05 & Lemon (piece) & Half & Half & Half \\
\hline 06 & Sodium benzoate & 1.2 & 1.2 & 1.2 \\
\hline
\end{tabular}

Sheet test in a steel plate, ladle test and droop test in a water beaker had also done simultaneously to determine the end point of jelly formation and pours the hot dilute jelly in the sterilized bottle. The bottles were then kept in a sound place to get it cool and to set jelly. A wax layer was given on the upper portion of the settled jelly. The bottles were then sealed and stored at an ambient temperature for further investigation.

\subsection{Jackfruit squash}

Formulations of the recipes were shown in the Table 5.

Table 5. Formulations for jackfruit squash

\begin{tabular}{|l|l|c|c|c|}
\hline Sl. & Ingredients & $\mathrm{T}_{1}$ & $\mathrm{~T}_{2}$ & $\mathrm{~T}_{3}$ \\
\hline 01 & Jackfruit juice $(\mathrm{ml})$ & 250 & 250 & 250 \\
\hline 02 & Sugar $(\mathrm{g})$ & 340 & 360 & 380 \\
\hline 03 & Citric acid $(\mathrm{g})$ & 11.5 & 10 & 5 \\
\hline 04 & Water $(\mathrm{ml})$ & 385 & 385 & 385 \\
\hline 05 & Lemon (piece) & 1 & 1 & 1 \\
\hline 06 & KMS & 0.6 & 0.6 & 0.6 \\
\hline
\end{tabular}

A flow diagram (Razzaque, 2007) ${ }^{[7]}$ of jackfruit squash is given in the Diagram 3.

Fully matured, fresh jackfruit was selected

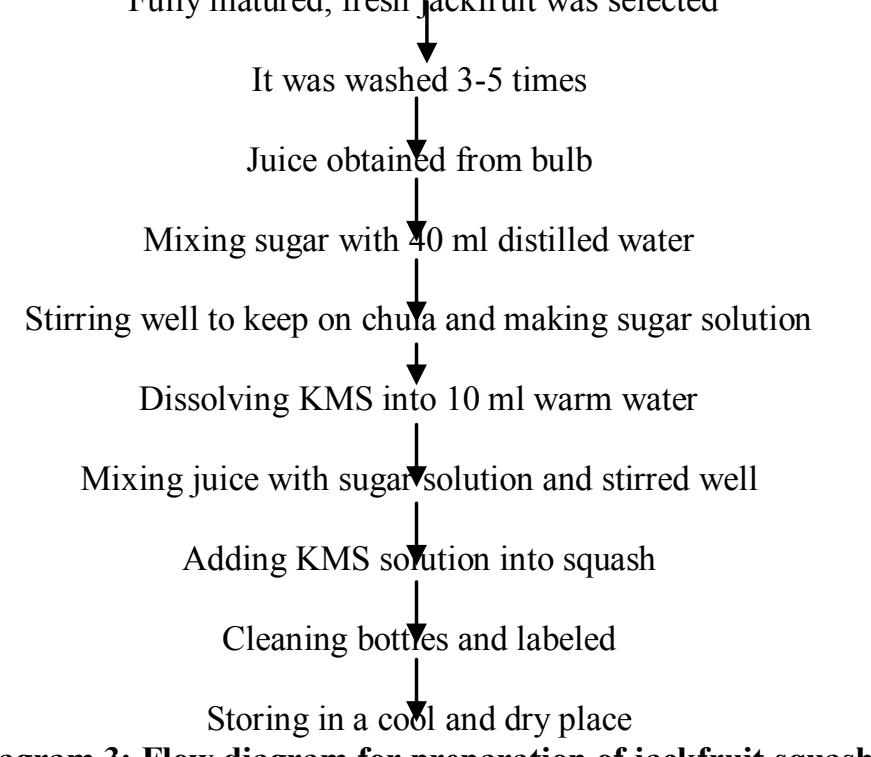

\subsection{Jackfruit sweet pickle}

Formulations of the recipes were shown in the Table 6.

Table 6. Formulations for jackfruit sweet pickle

\begin{tabular}{|c|l|c|c|c|}
\hline Sl. & Ingredients & $\mathrm{T}_{1}$ & $\mathrm{~T}_{2}$ & $\mathrm{~T}_{3}$ \\
\hline 01 & Jackfruit (g) & 500 & 500 & 500 \\
\hline 02 & Mustard oil (ml) & 100 & 100 & 100 \\
\hline 03 & Sugar (g) & 80 & 60 & 40 \\
\hline 04 & Zinger (g) & 9 & 9 & 9 \\
\hline 05 & Mustard powder (g) & 5.6 & 5.6 & 5.6 \\
\hline 06 & Turmeric (g) & 2.5 & 2.5 & 2.5 \\
\hline 07 & Cumin (g) & 1.5 & 1.5 & 1.5 \\
\hline 08 & Aniseed (g) & 1.5 & 1.5 & 1.5 \\
\hline 09 & Fenugreek (g) & 1.7 & 1.7 & 1.7 \\
\hline 10 & Black cumin (g) & 1.5 & 1.5 & 1.5 \\
\hline 11 & Cinnamon (g) & 1.5 & 1.5 & 1.5 \\
\hline 12 & Cardamom (piece) & 1 & 1 & 1 \\
\hline 13 & Vinegar (ml) & 100 & 100 & 100 \\
\hline 14 & Clove (piece) & 4 & 4 & 4 \\
\hline
\end{tabular}

A modified flow chart of jackfruit sweet pickle (Tilak, 1995) ${ }^{[6]}$ preparation is given in the Diagram 4.

Collection of Well-matured jackfruit 


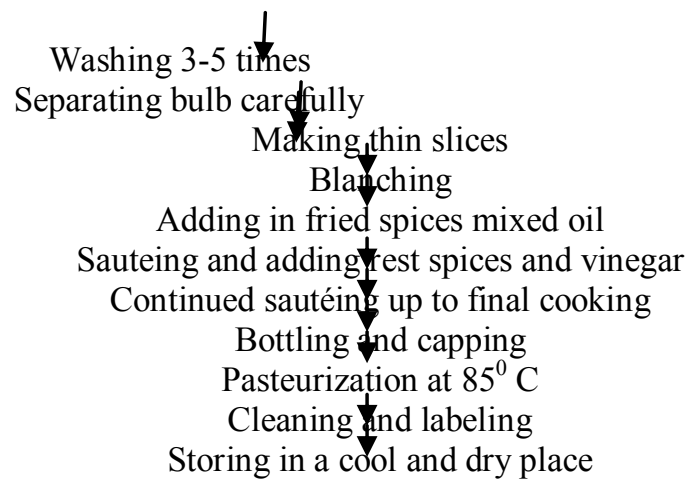

Diagram 4: Flow diagram for preparation of jackfruit sweet pickle

\subsection{Analysis of Processed Products}

Fresh raw material of jackfruit (Green and ripe) the finished products developed from them were analyzed for moisture content, $\mathrm{pH}$, total soluble solids (TSS), ascorbic acid and carotinoids. The determinations were done in triplicate for the treatment and the results were expressed as average value. These values were recorded as data against each individual item and were considered for analysis.

\subsection{Moisture content}

Moisture content of all the experimental samples was determined by thermo-statically controlled electric oven dry method. Empty aluminium cans with cover were taken, washed, dried, cooled and weighed. Then a definite quantity of samples were taken in the cans and weighed. The cans were placed in the oven and were dried at temperature $65^{\circ} \mathrm{C}$. After drying the cans were removed from the oven and cooled in desiccators. It was then weighed. The cans were placed again in the oven, dried and taken out of the drier, cooled in desiccators and weighed. Drying, cooling and weighing were repeatedly done until to gate a constant weight.

For accuracy, at least three samples were dried in the oven and percentages of moisture content were then calculated using the following formula:

Let,

Weight of empty aluminium can with lid

$=\mathrm{W}$

Weight of aluminium can + sample (Before drying) $\quad=\mathrm{W}_{1}$

Weight of aluminium can + sample (After drying) $\quad=\mathrm{W}_{2}$

So, the weight of sample

$=\mathrm{W}_{1}-\mathrm{W}$

And the weight loss of the sample

$=\mathrm{W}_{1}-\mathrm{W}_{2}$

Thus, percent moisture in the sample

$$
=\frac{\mathrm{W}_{1}-\mathrm{W}_{2}}{\mathrm{~W}_{1}-\mathrm{W}} \times 100
$$

\subsection{Determination of $\mathrm{pH}$ of Fruit Pulp}

The electrode assembly of the $\mathrm{pH}$ meter was dipped into the standard buffer solution of $\mathrm{pH} 7$ taken in a clean and dry beaker. The temperature correction knob was set to $28^{\circ} \mathrm{C}$ and the fine adjustment was made by asymmetry potential knob to $\mathrm{pH} 7$. After washing with distilled water the electrode assembly was dipped into a solution of standard $\mathrm{pH} 4$ and adjusted to the required $\mathrm{pH}$ by fine asymmetry potential knob. The electrode assembly was raised, washed twice with distilled water, and then rinsed with jackfruit juice and finally it was dipped into the juice of jackfruit and $\mathrm{pH}$ was recorded from the meter.

\subsection{Determination of Total Soluble Solid (TSS)}

The products were meshed into a mortar and a drop of products from these was placed on the prism of the refractometer and percent of total soluble solid was obtained from direct reading. Temperature correction was made as described by Ranaganna (1979) ${ }^{[8]}$.

\subsection{Determination of Vitamin C (ascorbic acid) Content}

2.11.1 Apparatus Used for the Estimation of Vitamin-C Content

Volumetric flask $250 \mathrm{ml}$., conical flask $250 \mathrm{ml}$, , beaker $150 \mathrm{ml}$, water bath, burette $250 \mathrm{ml}$. and pipette.

2.11.2 Reagents Used for the Estimation of Vitamin-C Content

1. 3\% Metaphosphoric Acid (HPO $\mathbf{H O}_{3}$ : It was prepared by dissolving the sticks of $\mathrm{HPO}_{3}$ in distilled water.

2. Standard Ascorbic Acid Solution 
3. Dye Solution: It was prepared by dissolving $260 \mathrm{mg}$ of the sodium salt of 2, 6-dichlorophenol indophenols in one litter of distilled water that contained $210 \mathrm{mg} /$ liter of sodium bicarbonate.

\subsubsection{Standardization of Dye Solution}

Five $\mathrm{ml}$ of standard ascorbic acid solution was taken in a clean beaker to which $5 \mathrm{ml}$ of $3 \%$ metaphosphoric acid solution was added with the help of a pipette. This solution was titrated against the dye till a faint pink color was obtained which persisted for more than 15 seconds.

\subsubsection{Estimation of Ascorbic Acid}

Thirty grams of products were weighed and blended with equal weight of $6 \%$ metaphosphoric acid for 3 to 4 minutes. Then 15 grams of this slurry was taken in a conical flask and was made up to the volume by adding $3 \%$ metaphosphoric acid. This juice was filtrated through a fast filter.

\subsubsection{Titration}

The burette was filled with standardized 2, 6-dichlorophenol indophenols dye reagent. $10 \mathrm{cc}$ of filtered solution was taken in a conical flask and titrated immediately against standard dye solution, till faint pink color was observed which persisted for not less than 15 seconds.

\subsubsection{Observation Chart:}

\begin{tabular}{|c|l|l|l|}
\hline Sl. No. & Initial burette reading & Final burette reading & Volume of alkali consumed (ml) \\
\hline 1 & & & \\
\hline 2 & & & \\
\hline 3 & & & \\
\hline Mean & & & \\
\hline
\end{tabular}

\subsubsection{Calculation}

Ascorbic acid mg per $100 \mathrm{~g}$ Sample $=\frac{V \times T}{W} \times 100$

Where,

$\mathrm{V}=$ Volume of dye used in titration against an aliquant diluted sample.

$\mathrm{T}=$ Value of standardized dye.

$\mathrm{W}=$ weight of pulp.

\subsection{Determination of Carotenoids (Vit-A)}

\subsubsection{Materials}

Acetone AR grade $80 \%$.

\subsubsection{Procedure}

1. $1 \mathrm{gm}$ of finely cut and well mixed fruit sample was weighted into a clean mortar.

2. The tissue sample was grinded to a fine pulp with addition of $20 \mathrm{ml}$ of $80 \%$ acetone.

3. It was centrifuged at $5000 \mathrm{rpm}$ for $5 \mathrm{mins}$ and transferred the supernatant to a $100 \mathrm{ml}$ of volumetric flask.

4. The residue was grinded with $20 \mathrm{ml}$ of $80 \%$ acetone, centrifuged and transferred the supernatant to the same flask.

5. The procedure was repeated until the residue was colourless. The pestle and mortar was washed thoroughly with $80 \%$ acetone and the clear washing was collected in the flask.

6. The volume was made to $100 \mathrm{ml}$ with $80 \%$ acetone.

7. The absorbance was read at 510 and $480 \mathrm{~nm}$ against blank.

\subsubsection{Calculations}

Where,

$$
\text { mg carotenoids } / \text { g tissue }=7.6(A .480)-1.49(A .510) \times \frac{V}{1000 \times 10}
$$

$A=$ Absorbance of the specific wave length

$\mathrm{V}=$ Final Volume of the Carotenoids in $80 \%$ acetone

$\mathrm{W}=$ Fresh weight of the tissue extracted 


\subsection{Storage Study}

All the prepared samples were stored at room temperature for a period of 12 months. The stored samples were examined by monthly. The colour, taste, flavour, texture and overall acceptability were examined during the storage period for about 12 months.

\subsection{Data Analysis}

The collected data were statistically analyzed by Analysis of Variance method. Least Significant Difference (LSD) was used to compare the means of different parameters.

\subsection{Product development from jackfruit}

\section{Results and Discussion}

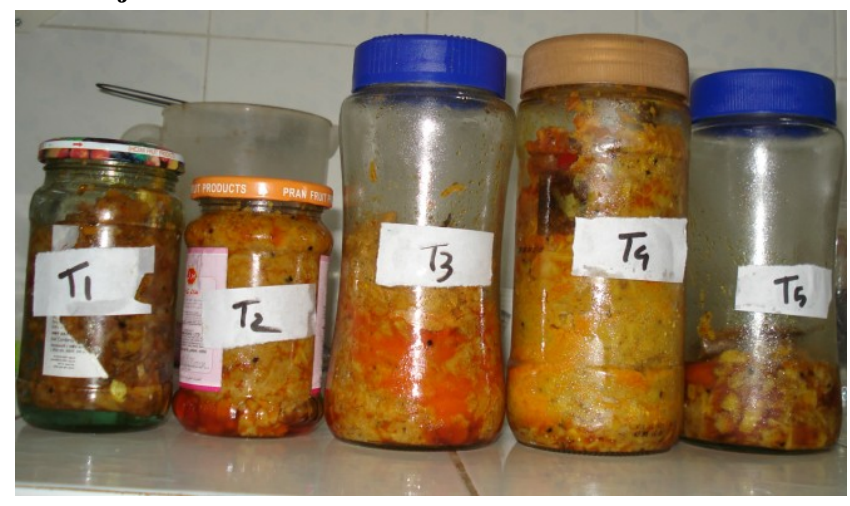

Plate 1: Green pickle developed by using green seeded jackfruit (Treatment $-1,2,3,4,5$ )

\subsection{Quantitative analysis of products developed from jackfruit}

\subsubsection{Quantitative analysis of raw material}

The chemical compositions of tender and ripe fresh jackfruit were analyzed taking $100 \mathrm{~g}$ of both separately. The data regarding the parameters are given in the Table 7.

Table 7. Composition of fresh jackfruit used in processed product development

\begin{tabular}{|c|c|c|}
\hline \multirow{2}{*}{ Parameters } & \multicolumn{2}{|c|}{ Stage of the fruit } \\
\hline & Green & Ripe \\
\hline Moisture (\%) & 85.00 & 76.51 \\
\hline $\operatorname{Ash}(\%)$ & 00.81 & 00.98 \\
\hline Protein $(\%)$ & 02.40 & 01.98 \\
\hline TSS (\%) & 14.50 & 22.00 \\
\hline Reducing sugar (\%) & 04.28 & 07.65 \\
\hline Non-reducing sugar $(\%)$ & 03.30 & 09.21 \\
\hline Total sugar $(\%)$ & 07.58 & 16.86 \\
\hline $\mathrm{p}^{\mathrm{H}}$ & 05.70 & 05.00 \\
\hline Ascorbic acid (mg/100 g) & 12.48 & 07.21 \\
\hline$\beta$-carotene $(\mu \mathrm{g} / 100 \mathrm{~g})$ & 86.31 & 198.00 \\
\hline Calcium (mg/100 g) & 31.22 & 20.15 \\
\hline $\operatorname{Iron}(\mathrm{mg} / 100 \mathrm{~g})$ & 01.46 & 00.58 \\
\hline Phosphorus (mg/100 g) & 38.13 & 41.51 \\
\hline
\end{tabular}

The results of analysis given in the above table are mostly similar as cited by Hossain (2000) ${ }^{[9]}$ and Bhatia et al. $(1955)^{[10]}$.

\subsubsection{Quantitative analysis of processed products}

Four products of jackfruit were selected among all the processed products after sensory evaluation on the basis of their acceptability. One treatment of each product which have performed best and gained the highest acceptability score was selected for chemical analysis. So the best treatment of jam, jelly, green pickle and sweet pickle were evaluated and their major chemical components were analyzed.

\subsubsection{Total Soluble Solids (Brix \%) content of products}

The difference of total soluble solids was significant among the 4 products (Appendix 1). The highest total soluble solids $(65.00 \%)$ were observed in jelly which was statistically similar $(64.00 \%)$ to jam. The least amount $(38.67 \%)$ of total soluble solids of fruit pulp was recorded from sweet pickle which was statistically similar $(46.67 \%$ ) to green pickle (Table 8). Average total soluble solids were found $53.583 \%$. 


\subsection{4 $\mathrm{pH}$ of products}

There was significant variation among the 4 products in respect of $\mathrm{pH}$ (Appendix 1). The highest $\mathrm{pH}$ (5.047) was found in jelly. The lowest $\mathrm{pH}$ content (4.117) was observed in jam which was statistically similar to Green Pickle (4.217) and Sweet Pickle (4.240) (Table 8). Average pH of was found 4.405.

\subsubsection{Vitamin C (ascorbic acid) Content of products}

Vitamin C content was significantly varied among the 4 products (Appendix 1). The highest vitamin $\mathrm{C}$ content $(3.4433 \mathrm{mg} / 100 \mathrm{~g})$ was found in green pickle and the lowest amount $(1.6133 \mathrm{mg} / 100 \mathrm{~g})$ was observed from jelly which was statistically similar $(1.7767 \mathrm{mg} / 100 \mathrm{~g}$ ) to jam (Table 4.8$)$. Average vitamin $\mathrm{C}$ was found as $2.259 \mathrm{mg} / 100 \mathrm{~g}$.

\subsubsection{Carotinoids (Vitamin A) content of products}

Significant variation was observed among the 4 products in respect of carotinoids content (Appendix 2). Green pickle contains the highest amount $(22.78 \mathrm{mg} / 100 \mathrm{~g})$ of carotinoids. Whereas jam showed the lowest amount $(9.607 \mathrm{mg} / 100 \mathrm{~g}$ ) of carotinoids (Table 8). Average carotinoids content was found $15.053 \mathrm{mg} / 100 \mathrm{~g}$.

\subsubsection{Moisture content of products}

Significant variation was observed among the 4 products in respect of moisture content (Appendix IX). Sweet pickle contains the highest amount $(50.95 \%)$ of moisture. Whereas jelly contains the lowest amount $(29.17 \%)$ of moisture (Table 8 ). Average moisture content was found $42.592 \%$.

Table 8. Major chemical components of jackfruit products

\begin{tabular}{|c|c|c|c|c|c|c|}
\hline Serial No. & $\begin{array}{l}\text { Name of the } \\
\text { Products }\end{array}$ & TSS (\%) & $\mathrm{p}^{\mathrm{H}}$ & $\begin{array}{l}\text { Vitamin C } \\
(\mathrm{mg} / 100 \mathrm{~g})\end{array}$ & $\begin{array}{l}\text { Carotinoids } \\
(\mathrm{mg} / 100 \mathrm{~g})\end{array}$ & Moisture (\%) \\
\hline 1 & Jam & $64.00 \mathrm{a}$ & $4.117 b$ & $1.7767 \mathrm{c}$ & $9.607 \mathrm{~d}$ & $41.76 \mathrm{c}$ \\
\hline 2 & Jelly & $65.00 \mathrm{a}$ & $5.047 \mathrm{a}$ & $1.6133 \mathrm{c}$ & $12.14 \mathrm{c}$ & $29.17 \mathrm{~d}$ \\
\hline 3 & Green Pickle & $46.67 \mathrm{~b}$ & $4.217 \mathrm{~b}$ & $3.4433 \mathrm{a}$ & $22.78 \mathrm{a}$ & $48.49 \mathrm{~b}$ \\
\hline \multirow[t]{4}{*}{4} & Sweet Pickle & $38.67 \mathrm{~b}$ & $4.240 \mathrm{~b}$ & $2.2033 \mathrm{~b}$ & $15.69 \mathrm{~b}$ & $50.95 \mathrm{a}$ \\
\hline & Average & 53.583 & 4.405 & 2.259 & 15.053 & 42.592 \\
\hline & $\begin{array}{l}\text { Level of } \\
\text { Significance }\end{array}$ & 0.01 & 0.01 & 0.01 & 0.01 & 0.01 \\
\hline & C.V \% & $5.95 \%$ & $1.48 \%$ & $7.47 \%$ & $4.12 \%$ & $1.79 \%$ \\
\hline
\end{tabular}

From the above scenario, it was evident that the TSS value of the processed products was much higher than the status found in raw material and it might be due to the use of different degree of sugar solution used in the experiments. The $\mathrm{pH}$ content of processed products was more or less similar to that of the raw material.

Ascorbic acid and carotinoid status of the processed products was much lower than the status found in raw material. These differences may be due to heat used in pasteurization and easily degradation characters of vitamins. The moisture content of the raw material was higher than that of the processed products. The lower moisture content of processed products might be due to heat used in cooking and pasteurization.

\subsection{Storage study of the processed products}

The processed products were stored in normal room temperature. After 6 month of storage, quality of the products was evaluated organoleptically by a taste-testing panel. It was found that even after six months of storage, quality of the processed products regarding color, taste, flavour and texture were similar to that of freshly processed products. Among the products, the quality of jelly especially the texture, after 8 months of storage started to deteriorate and gradually become watery after 9 months of storage. But the quality of squash especially taste and flavour after 7 months of storage started to deteriorate and gradually become spoiled. Some treatments of jam started to deteriorate after 8 months of storage but the best treatment remain unchanged. In the pickles (i.e., green pickle and sweet-pickle) the quality factor such as colour, taste, flavour and texture remain unchanged even after 12 months of storage. As the products were prepared without using any chemical preservatives, so, probably due to this reason the quality of jellies and jam started to deteriorate after 7 month of storage. And the main reason of deterioration of squash was high moisture and ascorbic acid content. Therefore, to prolong the shelf-life of the processed products, especially, in case of jelly, jam and squash, chemical preservatives that are not harmful for human health should be use in recommended dose approved by Bangladesh Standard and Testing Institute (Anonymous 2004 ${ }^{[11]}$; Anonymous 2005 ${ }^{[12]}$ ). 


\section{References}

[1]. M. Hassanullah, Bangladesh INSPIRED Action Plans for the Technical Study, 2013, http://euinspired.org.bd/docs/grant_scheme/INSPIRED\%20\%20Jackfruit\%20Report\%20\%20Jan\%20\%2713.pdf

[2]. Hossain M.M., A. Haque and M. Hossain, 1979. Nutritive value of Jackfruit, Bangladesh J. Agril., 1(2): 9-12.

[3]. BBS. 2007. Year book of Agricultural Statistics of Bangladesh. Bangladesh Bureau of Statistics. Ministry of Planning. People's Republic of Bangladesh.

[4]. SCUC. 2006. Jackfruit Artocarpus heterophyllus. Field manual for extension workers and farmers. SCUC, Southampton, UK.

[5]. Hossain M.M and M. A. Siddique. 1982. Taste and Visual Acceptibility of Some Exotic and Local Cultivars of Sweet Potato. Pakistan Journal of Scientific Research, 34 (3.4): 113-119.

[6]. B. Tilak, Ghare karo shilpo garo. (West Bengal State Book Board, Calcutta, India. 1995).

[7]. M..A. Razzaque, Khaddo prokrijatkoron (Bangla academi, Dhaka, Bangladesh. 2007).

[8]. S. Ranaganna. Lab manual analysis of fuits and vegetables products. (Tata Mc Graw Hill Publishng Company Ltd., New Delhi. 1979.)

[9]. Hossain M M., A.T.M.S. Choudhury, S.A. Chowdhury and S.S. chowdhury. 2000. Research and Development of Jackfruit in Bangladesh. In: Proc. of the 8th National Horticultural Workshop on Jackfruit-2000. BARC, Dhaka. pp. 1-120.

[10]. Bhatia, B.S., Siddapa and G. Lal. 1955. Composition and Nutritive value of Jackfruit. Ind. J. Agril. Sci., 25: $303-306$.

[11]. Anonymous, 2004. Bangladesh Standard Specification for Pickles (Second Revision). Bangladesh Standard and Testing Institute (BSTI), MAAN Bhaban, 116/A Tejgaon I/A, Dhaka-1208.pp:1-9.

[12]. Anonymous, 2005. Bangladesh Standard Specification for Jams, Jellies and Marmalades (Second Revision). Bangladesh Standard and Testing Institute (BSTI), MAAN Bhaban, 116/A Tejgaon I/A, Dhaka-1208.pp:1-14.

\section{Appendix I}

Analysis of variance of the data on product development (Rind jelly) from jackfruits

\begin{tabular}{|c|c|c|c|c|c|c|}
\hline \multirow{2}{*}{$\begin{array}{l}\text { Source of } \\
\text { variation }\end{array}$} & \multirow{2}{*}{$\begin{array}{l}\text { Degree of } \\
\text { freedom }\end{array}$} & \multicolumn{5}{|c|}{ Mean square } \\
\hline & & Colour & Taste & Flavour & Texture & Total \\
\hline Products & 3 & $10.05 * *$ & $6.60 * *$ & $12.45 * *$ & $10.20 * *$ & $117.60 * *$ \\
\hline Error & 16 & 0.675 & 1.125 & 0.45 & 0.45 & 4.275 \\
\hline Total & 19 & - & - & - & - & - \\
\hline
\end{tabular}

** = Significant at $1 \%$ level

Appendix II

Analysis of variance of the data on chemical characteristics of the products of Jackfruit

\begin{tabular}{|c|c|c|c|c|c|c|}
\hline \multirow[t]{2}{*}{ Source of variation } & \multirow{2}{*}{$\begin{array}{l}\text { Degree of } \\
\text { freedom }\end{array}$} & \multicolumn{5}{|c|}{ Mean square } \\
\hline & & TSS (\%) & $\mathrm{p}^{\mathrm{H}}$ & $\begin{array}{l}\text { Vitamin C } \\
(\mathrm{mg} / 100 \mathrm{~g})\end{array}$ & $\begin{array}{l}\text { Carotinoids } \\
(\mathrm{mg} / 100 \mathrm{~g})\end{array}$ & Moisture (\%) \\
\hline $\begin{array}{l}\text { Sample(Jackfruit } \\
\text { products) }\end{array}$ & 3 & $509.194 * *$ & $0.558 * *$ & $2.055 * *$ & $98.256^{* *}$ & $285.591 * *$ \\
\hline Error & 8 & 10.167 & 0.004 & 0.0285 & 0.3850 & 0.5830 \\
\hline
\end{tabular}

** = Significant at $1 \%$ level 